\title{
Diagnostic Effectiveness of Muscle Biopsy in Neuromuscular Diseases; Four Years of Retrospective Critical Review
}

\author{
Nöromüsküler Hastalıklarda Kas Biyopsilerinin Tanısal \\ Etkinliği; Dört Yıllık Geriye Dönük Eleştirisel inceleme
}

Özgün Araştırma Research Article

Alındığı tarih: 29.03 .2018

Kabul tarihi: 26.06.2018

Online Yayın tarihi: 26.03.2019

Bahattin Erdoğan Eskişehir Devlet Hastanesi, Patoloji Bölümü, Eskişehir, Türkiye bhttnrdgn@gmail.com ORCID: 0000-0001-9884-1112

S. Yimenicioğlu 0000-0002-1598-4423 Eskişehir Devlet Hastanesi, Pediatrik Nöroloji Bölümü, Eskişehir, Türkiye

C. Yarar 0000-0001-7462-4578 Eskişehir Osmangazi Üniversitesi Pediatrik Nöroloji Bölümü, Eskişehir, Türkiye

E. Özer 0000-0001-5743-5222 İzmir Dokuz Eylül Üniversitesi, Patoloji Ana Bilim Dalı, Izmir, Türkiye

K.B. Çarman 0000-0002-4629-1823 Eskişehir Osmangazi Üniversitesi Pediatrik Nöroloji Bölümü, Eskişehir, Türkiye

Cite as: Erdoğan B, Yimenicioğlu S, Yarar C, Özer E, Çarman KB. Diagnostic enffectiveness of muscle biopsy in neuromuscular diseases; Four years of retrospective critical riseases; Four Eğit. ve Araşt. Hast. Dergisi. 2019;29(1):37-46.

\author{
Bahattin Erdoğan $\odot$, Sevgi Yimenicioğlu $\odot$, Coşkun Yarar $\odot$, Erdener Özer $\odot$, \\ Kürşad Bora Çarman ${ }^{\oplus}$
}

\begin{abstract}
Objective: Most of the neuromuscular diseases have a genetic transmission and a progressive course, so it is important to make a timely and correct diagnosis in terms of management of the treatment, follow-up of the progression and genetic counseling to be provided to the family. The aim of this study is to analyze the histopathological evaluation process and results of muscle biopsies and to evaluate their contributions to the diagnostic and management decisions of the disease.

Methods: We retrospectively reviewed the results of muscle biopsies of 160 patients evaluated between 2013 and 2017 in our laboratory. The clinical presentations, initial diagnosis, adequacy of biopsy specimens, and pathology results were reviewed.

Results: Pediatric cases comprised $53.8 \%$ of the total cases and $60 \%$ of them being male patients. while $42.6 \%$ of the patients reported muscle weakness. Initial clinical diagnosis that required muscle biopsy was priorly myopathy/ dystrophy group with a rate of 60.1 percent. Histomorphological evaluation revealed myopathic/dystrophic changes in $71.2 \%$, and neuropathic changes in $9.4 \%$ of the cases. In $40 \%$ of total cases, the enzymatic and immunohistochemical staining could be used for further specifications of diagnosis or to exclude some diseases and allow molecular studies to be planned.

Conclusion: Muscle biopsy is indispensable for the establishment of an etiologic diagnosis. In the investigation of neuromuscular diseases, in addition to diagnostic data, histopathological examination is an integral part of the prediction of prognosis, and therapeutic planning. The efficiency of the histopathological study is directly proportional to the quality of the biopsy specimens. Development of clinicopathologic communication is a must in order to fulfill all criteria required for the management of the biopsy specimen. Pathologist's proactive role in the preanalytical process is important in terms of patient's safety and production of timely, and accurate results.
\end{abstract}

Keywords: Myopathy, muscle biopsy, muscular dystrophy

öz

Amaç: Nöromusküler hastalıkların çoğu genetik geçişli ve ilerleyici seyirli olup, tedavinin yönlendirilmesi, progresyonun takibi ve aileye verilecek genetik danışmanlık açısından zamanında doğru tanı konulması önemlidir. Bu çalışmanın amacı, kas biyopsilerinin histopatolojik değerlendirme süreç ve sonuçlarını analiz edip, hastalığın tanı ve yönetim kararlarına katkısını değerlendirmektir.

Yöntem: 2013-2017 çalışma döneminde laboratuvarımızda değerlendirilen 160 hastaya ait kas biyopsi sonuçları geriye dönük incelendi. Klinik sunumlar, ön tanı, biyopsi örnek yeterliliği ve patolojik sonuçları gözden geçirildi. Bulgular: Olguların \%60' erkek ve \%53,8'i pediyatrik yaş grubuna aitti. Hastaların \%42,6'sında kas güçsüzlüğü rapor edilmişti. Kas biyopsisini gerekli kılan ön tanı olarak myopati/distrofi grubu \%60,1 oranıyla ilk sıradaydı. Histomorfolojik değerlendirmede hastaların \%71,2'inde myopatik/distrofik bulgular, \%9,4'ünde nöropatik hastalık bulguları izlendi. Toplam olguların \%40'ında, enzimatik ve immünohistokimyasal boyamalar ile tanılar daha ileri spesifiye edilebildi ya da bir kısım hastalıklar dışlanarak moleküler çalışmaların planlanmasına olanak sağlandı. Sonuç: Kas biyopsisi etyolojik tanıyı olușturmak için vazgeçilmezdir. Nöromüsküler hastalıkların araștırılmasında, histopatolojik inceleme, tanısal verilerin yanı sıra prognostik öngörünün belirlenmesi ve terapötik planlamanın ayrılmaz bir bileșenidir. Histopatolojik araștırmanın verimi, kullanılan örneklerin kalitesi ile doğru orantılıdır. Numune yönetiminde tüm gerekliliklerin yerine getirilmesi için kliniko-patolojik iletişimin geliştirilmesi zorunludur. Patoloji uzmanının preanalitik süreçte proaktif rol alması hasta güvenliği ve zamanında, doğru sonuçların üretilmesi açısından önemlidir.

Anahtar kelimeler: Miyopati, kas biyopsi, müsküler distrofi

(C) Telif hakkı T.C. Sağlık Bakanlı̆ı İzmir Tepecik Eğit. ve Arașt. Hastanesi. Logos Tip Yayınclık tarafindan yayınlanmaktadı.

Bu dergide yayınlanan bütün makaleler Creative Commons Atf-GayriTicari 4.0 Uluslararası Lisansı ile lisanslanmıştır.

(c) Copyright Association of Publication of the T.C. Ministry of Health İmir Tepecik Education and Research Hospital.

This journal published by Logos Medical Publishing.

Licenced by Creative Commons Attribution-NonCommercial 4.0 International (CC BY-NC 4.0) 


\section{INTRODUCTION}

Most of the neuromuscular diseases have a genetic transmission and a progressive course, so it is important to make a timely and correct diagnosis in terms of management of the treatment, follow-up of the progression and genetic counseling to be provided to the family. In the investigation of pediatric and adult neuromuscular diseases, muscle biopsy has a critical role in providing diagnostic evidence for elucidating the etiology of the disease as well as realization of clinical examination, electrodiagnostic, laboratory and molecular genetic tests ${ }^{(1,2)}$.

The techniques used to diagnose muscle diseases have been developed rapidly. The application of molecular genetic testing and electron microscopy provides a true diagnostic opportunity that is the basis of patient management and also family counseling. However, these advanced diagnostic methods are not available for everyone, and not all patients can afford them. In such cases, routine histology, enzymatic and immunohistochemical staining continue to serve as a basis ${ }^{(3)}$.

Efficiency of pathological investigation relates with an accurate, timely and complete report. The pathological diagnostic process requires a comprehensive evaluation of the patient's clinical chart, laboratory abnormalities and pathologic findings. A poorly organized preanalytical process (determination of test requests, sample retrieval, preservation of the samples under appropriate conditions and their deliveries to the laboratory) may result in delayed acquirement of the analysis results, the production of inadequate/erroneous results, or recurrent biopsies ${ }^{(4)}$.

In neuromuscular diseases this requirement should be met compared with other clinical disciplines.

A comprehensive clinical history and examination, laboratory and imaging findings enable the appropri- ate diagnostic procedure to be applied for the use by the pathologist while they are also critical for the selection of the muscle to be biopsied ${ }^{(5)}$. For this reason, when a request for a biopsy is made, all the clinical findings about the patient must be declared to the pathologist to increase the efficiency of the pathological investigation.

Histological changes observed in muscle diseases are not usually specific, and the first prerequisite to make a good diagnosis is to provide detailed clinical information.

Since the pathology report provides a therapeutic guide for the clinician, concerning diagnostic categories so that normal, neuropathic, myopathic/dystrophic, inflammatory histologies etc. should be determined in the primary stage ${ }^{(6)}$. Even if pathology analyses do not reveal an accurate diagnosis, ruling out other diagnoses and the reporting all negative/ positive data obtained can contribute to the management of the disease ${ }^{(7)}$.

In our study, muscle biopsies evaluated between 2013 and 2017 were retrospectively analyzed for indications, clinical symptoms and findings, adequacy of the specimen and histopathological diagnosis. A panoramic view of the diseases is presented. In this way, the importance of pathologic evaluation in the diagnosis of neuromuscular diseases and the development of clinicopathological communication by fulfilling all the requirements of the parties in order to obtain more efficient results should be emphasized. Besides, the documented disease profiles will contribute to the national data base.

\section{MATERIALS and METHODS}

Evaluation of muscle biopsy specimens has been started on January 2013 in Anatomic Pathology Laboratories at Eskisehir State Hospital. Supportive had been received from Izmir 9 Eylül University Pathology Department for two years in order to 
achieve technical standards and academic experience. A retrospective study was carried out with 160 muscle biopsy specimens evaluated between 2013 and 2017 in the laboratory. All electronic hospital medical records and pathology reports were reviewed to get information about preanalytic and analytic process, gender, age, and symptoms of the patients, signs, age of onset of the symptoms, time elapsed between the onset of symptoms and muscle biopsy, family history, creatine kinase level (CK), electromyography (EMG) results, initial diagnosis, adequacy of specimen, and pathologic diagnosis.

The pathologic diagnosis was categorized in two groups. Pathologic diagnoses based on the essential morphological characteristics revealed by staining of the specimens with routine hematoxylin-eosin (H\&E) and histochemical stains (modified Gomori trichrome, periodic acid-schiff (PAS), Oil Red O/Sudan Black B) were included in the first category. In the second category, diagnosis/interpretation related to etiology based on the evaluation of the results of enzymatic histochemical stains [adenosine triphosphatase (ATPase) pH 4,2-10,4, nicotinamide adenine dinucleotide-tetrazolium reductase (NADH-TR), succinate dehydrogenase $(\mathrm{SDH})$, cytochrome $\mathrm{C}$ oxidase (COX), acid phosphatase, alkaline phosphatase, phosphorylase, phosphofructokinase] and immunohistochemical [dystrophin (Rod domain, N-terminus, C-terminus) tests, sarcoglycan (alpha, beta, gamma, delta), merosin, utrophin, Collagen $\mathrm{VI}$, alpha dysroglycan, MHC class1, Dysferlin, Lamin A/C, Emerin, Caveolin-3, Calpain-3, p62, Neonatal myosin, Slow myosin and Fast myosin]. Information on the post analytic process was obtained from clinical assessments (enzyme analyses, genetic tests etc.) and final clinicopathologic diagnosis. Acquired data were analyzed using IBM SPSS (Version 24).

\section{RESULTS}

Muscle biopsy specimens belonged to 86 (53.8\%) children, and $74(46.2 \%)$ adults, with an overall male/female ratio of 60/40. In children, and adults male/female ratios were $70.9 / 29$, and 52.7/47.3, respectively. Muscle weakness was the most common associated symptom in $42.6 \%$ ( $\mathrm{n:66)}$, hypotonic infant in $15.5 \%$ ( $\mathrm{n}: 24)$, fatigue in $12.9 \%$ ( $\mathrm{n}: 20)$ and coincident high CK levels in $11.6 \%$ ( $n: 18)$ of the cases.

Time interval between the onset of the symptoms and muscle biopsy ranged between one month and 360 months, with a median of 57 months (children:23 months, adults: 98 months). EMG was performed before biopsy in $50.6 \%$ ( $\mathrm{n}: 81$ ) (children: 22.1\%, adults: $83.8 \%$ ) of the cases. Myopathic changes were found in 52 (32.5\%) of these cases. CK levels were measured in $71.2 \%$ ( $n: 114)$ of the cases, and these patients had normal (27.5\%: n:44), slightly elevated (15.6\%: n:25), and increased (28.1\%: n:45) CK levels. Consanguinity or suspected family history of muscle disease was detected in 33.1\% ( $: 53$ ) of the cases. Fifty-three (33.1\%) patients ( $\mathrm{n}: 53$ ) had negative family history (Table 1, Graph 1).

Preliminary clinical diagnosis before muscle biopsy was myopathy/dystrophy in $60.1 \%$ (n:96) [myopathy in 41.9\% (n:67), myopathy/dystrophy in 14.4\% (n:23), and dystrophy in $3.8 \%$ (n:6)] of the cases. Eighteen (11.3\%) patients were investigated for the etiology of high CK levels, while metabolic/mitochondrial disease was detected in $10 \%$ ( $n: 16)$, hypotonia of infancy in $6.9 \%$ ( $\mathrm{n}: 11)$, inflammatory myopathy in $7.5 \%$ ( $n: 12$ ) of the cases (Table 2, Graph 2). Routine histological evaluation revealed the diagnosis of myopathy/dystrophy in $71.2 \%$ ( $n: 114)$ of the cases, and $56.1 \%$ ( $n: 64)$ of these ( $40 \%$ of all patients) were rather specified with enzymatic, histochemical and immunohistochemical methods. A neuropathic change has been observed in $9.4 \%$ of the cases. Nonspecific, and normal muscle biopsy results were revealed in $8.8 \%$ ( $n: 14)$, and $10.6 \%$ ( $n: 17)$ of the cases, respectively. Secondary diagnosis with additional tests revealed DMD/BMD in $11.3 \%$ ( $n: 18)$, metabolic/mitochondrial diseases in 9.4\% (n:15), 
Table 1. Distribution of clinical features ( $\mathrm{n}$ : count).

\begin{tabular}{|c|c|c|c|c|c|}
\hline Age & Sex & $\begin{array}{l}\text { EMG } \\
\mathrm{n}: 81\end{array}$ & $\begin{array}{l}\text { CK } \\
\mathrm{n}: 114\end{array}$ & $\begin{array}{l}\text { Family history } \\
\mathrm{n}: 106\end{array}$ & $\begin{array}{l}\text { First symptom } \\
\mathrm{n}: 155\end{array}$ \\
\hline \multirow{7}{*}{$0-18: n=86 \quad(53.8 \%)$} & $f: 25,29.1 \%$ & Normal: 6 (7\%) & Normal: 23 (26.7\%) & Positive: 30 (34.9\%) & $\begin{array}{l}\text { Exercise intolerance: } 3 \text { (3.5\%) } \\
\text { Fatigue: } 4(4.7 \%)\end{array}$ \\
\hline & \multirow[t]{6}{*}{$m: 61,70.9 \%$} & Myopathy: 11 (12.8\%) & Mild increased: 9 (10.5\%) & Negative: 24 (27.9\%) & $\begin{array}{l}\text { Weakness: } 23(26.7 \%) \\
\text { Contracture: } 5(5.8 \%)\end{array}$ \\
\hline & & Neuropathy: 2 (2.3\%) & Increased: 23 (26.7\%) & Unknown: 32 (37.2\%) & $\begin{array}{l}\text { Cramp: } 1(1.2 \%) \\
\text { Myalgy: } 2(2.3 \%)\end{array}$ \\
\hline & & Unknown: 67 (77.9\%) & Unknown: 31 (36\%) & & Hypotonic Infant: 24 (27.9\%) \\
\hline & & & & & High CK: 14 (16.3\%) \\
\hline & & & & & Ptosis, dysartria: 3 (3.5\%) \\
\hline & & & & & Neuromotor disturbance: 4 (4.7\%) \\
\hline \multirow{6}{*}{$18>: n=74(46.3 \%)$} & $f: 39,52.7 \%$ & Normal: 11 (14.9\%) & Normal: 21 (28.4\%) & Positive: 23 (31.5\%) & $\begin{array}{l}\text { Exercise intolerance: } 4 \text { (5.4\%) } \\
\text { Fatigue: } 16(21.6 \%)\end{array}$ \\
\hline & \multirow[t]{5}{*}{$m: 35,47.3 \%$} & Myopathy: 41 (55.4\%) & Mild increased :16(21.6\%) & Negative: 29 (39.2\%) & Weakness: 43 (58.1\%) \\
\hline & & & & & Myalgy: $3(4.1 \%)$ \\
\hline & & Neuropathy: 10 (13.5\%) & Increased: 22 (29.7\%) & & Stifness: $1(1.4 \%)$ \\
\hline & & Unknown: 12 (16.2\%) & Unknown:15 (20.3\%) & Unknown: 22 (29.7\%) & High CK: 4 (5.4\%) \\
\hline & & & & & Neuromotor retardation: 1 (1.4\%) \\
\hline \multirow{10}{*}{ 0-73: $n=160$} & $f: 64,40 \%$ & Normal: 17 (10.6\%) & Normal: 44 (27.5\%) & Positive: 53 (33.1\%) & $\begin{array}{l}\text { Exercise intolerance: } 7 \text { (4.5\%) } \\
\text { Fatigue: } 20 \text { (12.9\%) }\end{array}$ \\
\hline & \multirow[t]{9}{*}{$m: 96,60 \%$} & \multirow[t]{2}{*}{ Myopathy: 52 (32.5\%) } & \multirow[t]{2}{*}{ Mild increased: $25(15.6 \%)$} & \multirow[t]{3}{*}{ Negative: 53 (33.1\%) } & Weakness: 66 (42.6\%) \\
\hline & & & & & Contracture: 5 (3.2\%) \\
\hline & & \multirow[t]{2}{*}{ Neuropathy 12 (7.5\%) } & \multirow[t]{2}{*}{ Increased: 45 (28.1\%) } & & Cramp $1(0.6 \%)$ \\
\hline & & & & \multirow[t]{6}{*}{ Unknown: 54 (33.8\%) } & Myalgy 5 (3.2\%) \\
\hline & & Unknown: 79 (49.4\%) & Unknown : 46 (28.8\%) & & Stifness: $1(0.6 \%)$ \\
\hline & & & & & Hypotonic infant: 24 (15.5\%) \\
\hline & & & & & High CK: 18 (11.6\%) \\
\hline & & & & & Ptosis, dysartria: 3 (1.9\%) \\
\hline & & & & & Neuromotor retardation: 5 (3.1\%) \\
\hline
\end{tabular}

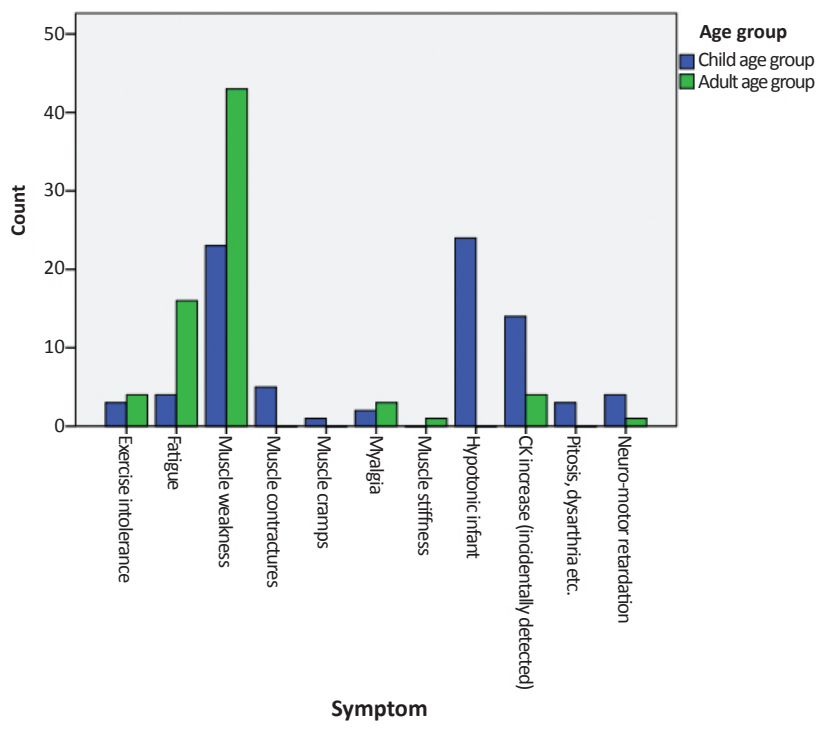

Graph 1. Distribution of reported symptoms according to adult and child age groups.

dysferlinopathies in 6.3\% ( $\mathrm{n}: 10)$, inflammatory myopathies in 5\% (n:8) (DM:1, PM:4, IBM:3), lipid stor- age disease in $1.9 \%(n: 3)$, glycogen storage disease in $1.9 \%$ ( $n: 3)$, sarcoglycanopathies in $1.3 \%(n: 2)$, alpha dystroglycanopathies in $1.3 \%$ ( $\mathrm{n}: 2$ ), myotonıc dystrophy in $0.6 \%(n: 1)$, central core disease in $0.6 \%(n: 1)$ of the patients (Table 2, Graph 2,3,4). Genetic study results were available for 29 patients which revealed myopathy/dystrophy in 22, neuropathies in 2, and 3 nondiagnostic abnormal findings in 3 patients. As a result of these evaluations, only one case with mitochondrial myopathy could not be genetically confirmed (Table 3).

\section{DISCUSSION}

The quality of work produced by the laboratory is only as good as the quality of the samples used for testing. In order to produce accurate test results, the pathologist should take a proactive approach to ensure the proper organization of the sample man- 
B. Erdoğan ve ark., Diagnostic Effectiveness of Muscle Biopsy in Neuromuscular Diseases; Four Years of Retrospective Critical Review

Table 2. Prediagnosis, pathological diagnosis distrubition (C: Child age group ; A: adult age group ; T:total case; n: count).

\begin{tabular}{|c|c|c|c|c|c|c|c|c|c|c|c|}
\hline $\begin{array}{l}\text { Clinical preliminary } \\
\text { diagnosis }\end{array}$ & $\begin{array}{c}\mathrm{C} \\
\mathrm{n}: 86\end{array}$ & $\begin{array}{c}\mathrm{A} \\
\mathrm{n}: 74\end{array}$ & $\begin{array}{c}\mathrm{T} \\
\mathrm{n}: 160\end{array}$ & $\begin{array}{l}\text { First Pathologic } \\
\text { diagnosis }\end{array}$ & $\begin{array}{c}\text { Ç } \\
\mathrm{n}: 86\end{array}$ & $\begin{array}{c}\text { A } \\
\mathrm{n}: 74\end{array}$ & $\begin{array}{c}\mathrm{T} \\
\mathrm{n}: 160\end{array}$ & $\begin{array}{l}\text { Second Pathologic } \\
\text { diagnosis }\end{array}$ & గ̧:34 & $\begin{array}{c}A \\
\mathrm{n}: 31\end{array}$ & $\begin{array}{c}\mathrm{T} \\
\mathrm{n}: 64\end{array}$ \\
\hline High CK? & 14 & 4 & $18(11.3 \%)$ & Normal histology & 12 & 5 & $17(10.6 \%)$ & $\mathrm{DMD} / \mathrm{BMD}$ & 15 & 3 & $18(11.3 \%)$ \\
\hline Myopathy & 24 & 43 & 67 (41.9\%) & $\begin{array}{l}\text { Myopathy/dystrophy } \\
\text { specified }\end{array}$ & 34 & 30 & $64(40.6 \%)$ & Sarcoglycanopathy & 2 & - & $2(1.3 \%)$ \\
\hline $\begin{array}{l}\text { Dystrophy } \\
\text { DMD/BMD, } \\
\text { LGMD, MD }\end{array}$ & 13 & 10 & $23(14.4 \%)$ & $\begin{array}{l}\text { Myopathy/dystrophy } \\
\text { unspecified }\end{array}$ & 26 & 24 & $50(31.3 \%)$ & Dysferlinopathy & 4 & 6 & $10(6.3 \%)$ \\
\hline Myopathy/Dystrophy & 5 & 1 & $6(3.8 \%)$ & $\begin{array}{l}\text { Neuropathic, } \\
\text { (that explain } \\
\text { phenotype) }\end{array}$ & 3 & 4 & $7(4.4 \%)$ & Alpha dystroglycanopathy & 2 & - & $2(1.3 \%)$ \\
\hline $\begin{array}{l}\text { Hypotonic Infant } \\
\text { Myopathy }\end{array}$ & 11 & - & $11(6.9 \%)$ & $\begin{array}{l}\text { Neuropathic, } \\
\text { (does not explain } \\
\text { phenotype) }\end{array}$ & 4 & 4 & $8(5 \%)$ & $\begin{array}{l}\text { Inflammatory myopathy } \\
\text { DM (PM, IBM) }\end{array}$ & 1 & 7 & $8(5 \%)$ \\
\hline Inflammatory myopathy & 1 & 11 & $12(7.5 \%)$ & $\begin{array}{l}\text { Insufficient findings } \\
\text { for diagnosis }\end{array}$ & 7 & 7 & $14(8.8 \%)$ & Lipid Storage Disease & 1 & 2 & $3(1.9 \%)$ \\
\hline $\begin{array}{l}\text { Metabolic/Mitochondrial } \\
\text { disease }\end{array}$ & 15 & 1 & $16(10 \%)$ & & & & & $\begin{array}{l}\text { Metabolic/Mitochondrial } \\
\text { disease }\end{array}$ & 4 & - & $4(2.5 \%)$ \\
\hline Congenital myopathy & 1 & - & $1(0.6 \%)$ & & & & & Mitochondrial myopathy & 4 & 7 & 11 (6.9\%) \\
\hline $\begin{array}{l}\text { Congenital muscular } \\
\text { dystrophy }\end{array}$ & 1 & - & $1(0.6 \%)$ & & & & & Myotonic dystrophy & 1 & - & $1(0.6 \%)$ \\
\hline $\begin{array}{l}\text { Neuropaty R/O } \\
\text { Myopathy }\end{array}$ & - & 4 & $4(2.5 \%)$ & & & & & Central core disease & - & 1 & $1(0.6 \%)$ \\
\hline \multirow[t]{2}{*}{$\begin{array}{l}\text { M.Gravis, R/O } \\
\text { myopathy }\end{array}$} & 1 & - & $1(0.6 \%)$ & & & & & Glycogen storage disease & - & 3 & $3(1.9 \%)$ \\
\hline & & & & & & & & $\begin{array}{l}\text { Tibial distal myopathy } \\
\text { supportin diagnosis }\end{array}$ & - & 1 & $1(0.6 \%)$ \\
\hline
\end{tabular}

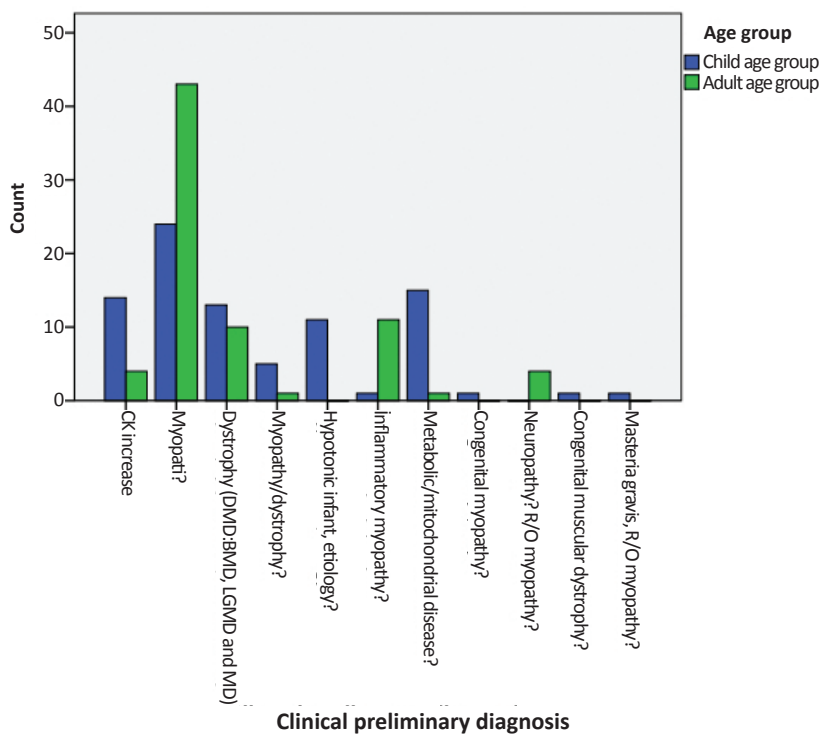

Graph 2. Distribution of clinical preliminary diagnosis according to adult and child age groups.

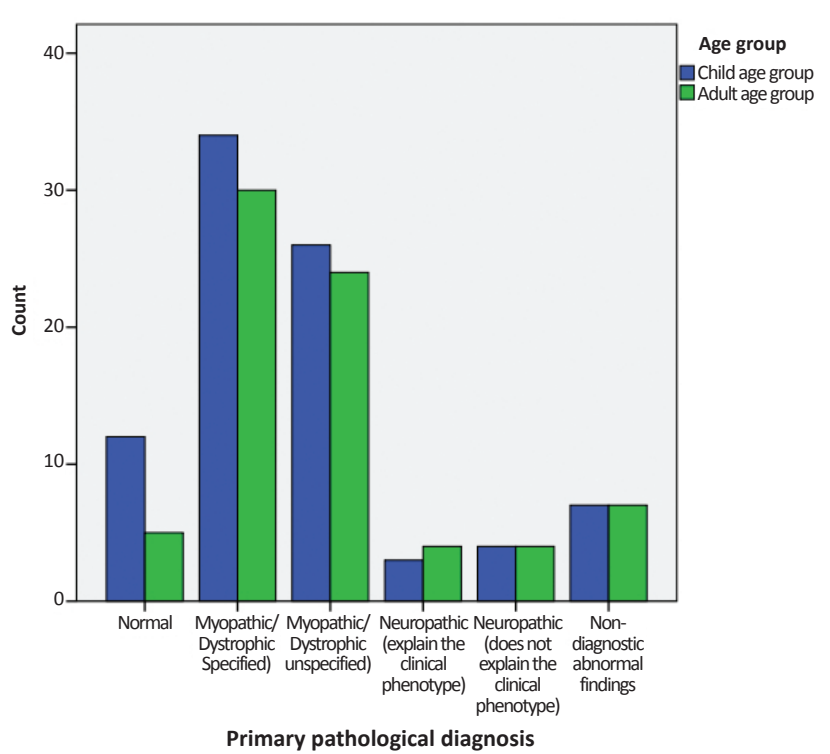

Graph 3. Distribution of primary pathologic diagnoses according to adult and child age groups. 


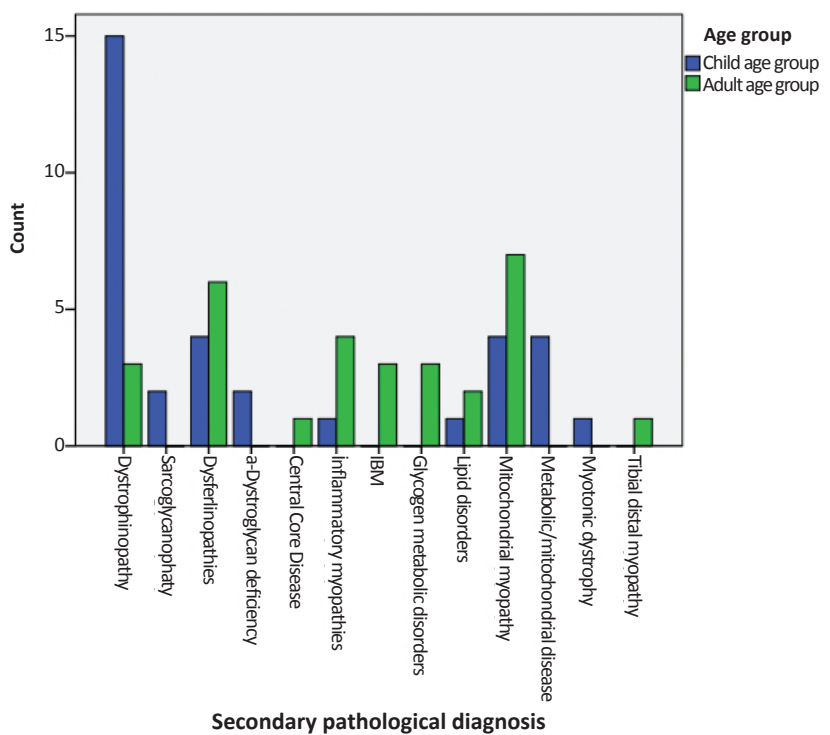

Graph 4. Distribution of secondary pathologic diagnoses according to adult and child age groups.

Table 3. Secondary pathological diagnosis * Genetic diagnosis, Crosstabulation.

\begin{tabular}{|c|c|c|c|c|}
\hline & & \multicolumn{2}{|c|}{ Genetic diagnosis } & \multirow[b]{2}{*}{$\begin{array}{c}\text { Total } \\
\text { (count) }\end{array}$} \\
\hline & & $\begin{array}{l}\text { Examined } \\
\text { (supports } \\
\text { pathology) }\end{array}$ & $\begin{array}{l}\text { Examined } \\
\text { (not } \\
\text { supporting } \\
\text { pathology) }\end{array}$ & \\
\hline \multirow{6}{*}{$\begin{array}{l}\text { Myopathic/ } \\
\text { Dystrophic } \\
\text { (Specified): } \\
\text { Secondary } \\
\text { pathological } \\
\text { diagnosis }\end{array}$} & Dystrophinopathy & 9 & 0 & 9 \\
\hline & Dysferlinopathies & 4 & 0 & 4 \\
\hline & $\begin{array}{l}\text { Glycogen metabilıc } \\
\text { disorders }\end{array}$ & 3 & 0 & 3 \\
\hline & Lipid dısorders & 2 & 0 & 2 \\
\hline & $\begin{array}{l}\text { Mitochondrial } \\
\text { myopathy }\end{array}$ & 3 & 1 & 4 \\
\hline & Myotonic dystrophy & 1 & 0 & 1 \\
\hline $\begin{array}{l}\text { Neuropathic } \\
\text { (explain the } \\
\text { clinical } \\
\text { phenotype) }\end{array}$ & & 2 & 0 & 2 \\
\hline $\begin{array}{l}\text { Non-diagnostic } \\
\text { abnormal } \\
\text { findings }\end{array}$ & & 3 & 0 & 3 \\
\hline Normal & & 1 & 0 & 1 \\
\hline Total & & 28 & 1 & 29 \\
\hline
\end{tabular}

agement, all requirements, and to establish a proper communication with the clinical practitioner ${ }^{(4)}$.

Retrieval, preservation, transfer and processing of specimens from cases suspected of neuromuscular disease are different from routine pathological evaluation procedures. The surgeon must have been informed about biopsy techniques in order to obtain a viable muscle biopsy specimen. Preservation of the enzymatic activity of the tissue samples obtained, and delivered to the laboratory as fresh as possible are essential issues. Tests applied to specimens should be decided before muscle biopsy. If performance of the biochemical tests is ensured, then a little amount of specimen ( $50 \mathrm{mg}-500 \mathrm{mg}$ ) should be obtained at the operation room, wrapped with folio, embedded into liquid nitrogen and kept frozen at $-70^{\circ} \mathrm{C}$ till transfer. The tissue specimen with a weight of $50 \mathrm{mg}$ (less than $2 \mathrm{~mm}$ ) should be fixed with $4 \%$ glutaraldehyde for electron microscopic examination . The specimen should be transferred within 15-20 minutes to the laboratory with a sponge soaked in serum physiologic. If the transfer will take 1-2 hours then the moisturized sponge must be placed in ice pack, if it takes longer than 2 hours, then the tissue must be wrapped with folio, placed in liquid nitrogen and preserved at $-80^{\circ} \mathrm{C}$ in dried ice ${ }^{(1,2,7)}$.

The patients who were followed and treated in Eskisehir State Hospital ESH and Eskisehir Osmangazi University Medical Faculty (ESOGU) Hospitals were evaluated. Efforts were spent to maximize the flow of information, develop and improve relationships among pathologists and clinicians. The pathologist gives information at the clinical trainings about preanalytical process of muscle biopsies and organizes retrieval of biopsy specimens and their transfer to the laboratory in case of need. Additional consultations for the evaluations of muscle biopsy specimens were organized with Pathology Departments of 9 Eylül University Faculty of Medicine and Tepecik Education and Search Hospital. 
Fixative solution for pathological evaluation was erroneously prepared for only 5 of 160 specimens. In these cases, the surgeon or clinical physician had not been contacted before. This emphasizes the importance of clinicopathological communication and flow of information.

Physical examinations and taking accurate medical history are the main cornerstones for the diagnosis, and treatment of neuromuscular diseases. Laboratory results (blood tests, electrodiagnostic studies, muscle biopsy, molecular genetic studies) have confirmatory roles for diagnosis ${ }^{(8,9)}$. Prioritization of laboratory examinations, muscle biopsy and other advanced tests for initial clinical diagnosis should be planned. Muscle biopsy request forms should contain clinical, physical examination, and important laboratory findings, family history, initial diagnosis, doctor's name, and contact information.

In pathological evaluation, improved communication and information exchange between the clinician and the pathologist is very important in interpreting the findings as well as the histopathological features of the tissue. In the light of the initial diagnoses and clinical findings, additional examinations other than routine morphological examinations may contribute to the diagnosis $(1,2,5,7,10)$.

The first step in the clinical approach is to obtain adequate and accurate symptomatic information ${ }^{(1,2)}$. Information concerning signs and symptoms was available in $96.9 \%$ of the patients. Muscle weakness was the most common sign in $42.6 \%$ of the patients in our study. If muscular weakness involved proximal part of legs and arms myopathy is the most probable diagnosis, and distal myopathy is less probable at this circumstance. Fatigue, exercise intolerance, general condition, cardiopulmonary state, sleeping habits of the patient, may correlate with emotional state of the patient so these features are less reliable diagnostic symptoms. If the neurologic examination is normal, then general weakness and fatigue do not correlate with the diagnosis of myopathy but the duration of the exercise that accounts for fatigue and weakness is important ${ }^{(7,9)}$. Exercise intolerance and fatigue were detected in $17.4 \%$ of the cases. Myalgia is a nonspecific symptom of some myopathies which was found in $3.2 \%$ of our cases. Myalgia may be episodic as seen in metabolic myopathies or persistent as seen in inflammatory myopathies. Muscle pain is not a feature of muscle disease in general, instead it may be seen with orthopedic or rheumatologic diseases. Nonspecific muscle pain rarely indicates muscle disease when the neurologic examination and laboratory studies are unremarkable. Muscle cramps rarely correlate with the diagnosis of primary myopathy. The cramps are mostly seen in association with dehydration, hyponatremia, azotemia, myxedema, motor neuron or neurological diseases (especially lateral amyotrophic myopathy), and they do not correlate with underlying myopathy. Only one of our study patients had cramps.

Muscle contractures are rare but superficially cramplike. Glycolytic enzyme deficiencies are generally provocative for cramps induced with exercise $(1,2,7,9)$ which was seen in $2.5 \%$ of our study patients.

Hypotonic infant is a feature of some muscular diseases like spinal muscular atrophy (SMA), congenital muscular dystrophy (CMD), and congenital myopathy. Evaluation of muscle biopsy is essential for the diagnosis of neuromuscular hypotonia ${ }^{(11)}$. In our study hypotonia was the most common symptom in $27.9 \%$ of pediatric cases while its overall incidence was 15.5 percent. Age at onset of the symptoms, duration, and course of the disease are important contributing factors which were all reported in $86 \%$ of the cases. Age at onset is also important as a diagnostic criterion. e.g. symptoms of Duchenne muscular dystrophy usually start by three years of age, whereas symptoms of facioscapulohumeral muscular dystrophy (FSH) and limb-girdle dystrophy (LGMD) become manifest by or after adolescence. Myopathy may cause constant weakness (inflammatory myo- 
pathy, muscle dystrophy) or episodic weakness (glycolytic pathway disturbances, periodic paralysis). Episodic disorders are characterized by acute muscular weakness resolving within hours or days $(1,2,7,9)$.

Family history was also important in our study which was found in $66.2 \%$ of the cases. In most of the cases myopathy are transmitted genetically, therefore family history carries importance. Family tree must be known to determine the presence (if any) autosomal dominant, recessive, $X$-linkedinheritance. Identification of a specific hereditary pattern is critical not only for a correct diagnostic approach but also for the appropriate genetic counseling. In our study, family history was not indicated in one third of the patients.

The fact that half of the reported cases have consanguineous marriages or related to the presence of individuals with suspect muscular disease, suggests that kinship marriages should be avoided in order to reduce the incidence of these group of diseases.

Increase in serum CK levels indicates the presence of striated or heart muscle damage (necrosis). CK levels should be measured, and EMG should be performed before muscle biopsy. CK may be slightly, moderately or highly elevated in muscle disease $(1,2,7,12)$. In our study high CK levels were reported in $71.2 \%$ of all, and $64 \%$ of pediatric cases. Myopathic/ dystrophic findings were detected in 10 of 18 asymptomatic cases with elevated CK. Although asymptomatic patients with elevated CK levels had abnormal muscle biopsy findings, lesser number of them were diagnosed as having muscular dystrophy ${ }^{(11)}$. Especially after exercise, CK levels may be elevated in normal persons. Falling from a height, intramuscular injections, hematoma, and some drugs may elevate CK levels. Asphyxic newborns may have CK levels higher than 1000 IU/L. CK levels may increase in healthy newborns within the first postnatal 24 hours. A normal CK level does not rule out muscle disease, and CK levels may be normal in some muscle diseases ${ }^{(13)}$.
Electromyography (EMG) is useful for differential diagnosis between denervation myopathy, myotonia, and neuromuscular junction disease. Small, lowamplitude, polyphasic motor unit potentials (MUP) are seen in diseases with myopathy, while denervation potentials, fasciculations, fibrillations, sharp waves, wide, long polyphasic MUPs are seen in neuropathies. Myotonic discharges may be seen in congenital myotonic dystrophy ${ }^{(14)}$. In our series, and in pediatric population, myotonic discharges were reported in $51.6 \%$, and $22.1 \%$ of the cases, respectively. Besides, histological findings, family history, CK, EMG results are also important for the establishment of diagnosis but they are reported at a low rate in pediatric population (Table 1). These reported lower rates may be due to the ineffective communication between other centers that we collaborated with. Electromyography is also hard to perform during process of myopathy in pediatric population. Because sufficient muscle contraction may not be elicited among children, so precise results may not be obtained ${ }^{(14)}$.

Muscular dystrophies (dystrophinopathy, sarcoglycanopathy, merosinopathy and others), congenital myopathies, inflammatory myopathies (dermatomyositis, polymyositis, inclusion body myositis), vasculitis, especially metabolic myopathies (Pompe disease, McArdle disease, Tarui disease, Iysosomal storage disease, lipid myopathies, mitochondrial myopathies) are the primary diseases that require muscle biopsy. In our study findings of myopathy/ dystrophy were detected in $60.1 \%$, asymptomatic high CK levels in $11.3 \%$, metabolic/mitochondrial disease in $10 \%$, inflammatory myopathy in $7.5 \%$ and hypotonic infant in $6.9 \%$ of the patients (Table 2, Graph 2).

Symptoms, and signs of myopathy/dystrophy were observed in $71.2 \%$ of the patients in our study. More than half of these cases could be diagnosed or else molecular tests could be planned. Changes related to neuropathic diseases were found in $9.4 \%$ of the 
cases. In other patients, the histologic analysis demonstrated normal, mildly pathologic or nondiagnostic changes (Table 2, Graph 3). These rates showed that initial clinical diagnoses were confirmed in large measure with histopathological studies. These findings suggest that clinical practitioners behave selectively in muscle biopsy planning.

Enzymatic and immune histochemical analyses performed in muscle biopsy evaluations allow recognition of additional histopathological changes. In this way, more accurate and specific diagnoses can be made. However, in patients with phenotypic findings suggesting a specific hereditary muscle disorder in the family history, conduction of genetic tests should be considered in blood or tissue specimens ${ }^{(1,2,15)}$.

In the study, 64 cases could be further specified by additional investigations. These diseases were classified as dystrophinopathy ( $\mathrm{n}: 18)$, mitochondrial disease $(n: 11)$, dysferlinopathy ( $n: 10)$, inflammatory myopathy $(n: 8)$, glycogen storage disease $(n: 3)$, lipid storage disease (n:3), and others (Table 2, Graph 4). Since the majority of neuromuscular diseases have an important genetic dimension, demonstration of the genetic defect confirms the diagnosis. However, most genetic studies are restricted to only researches. Routine tests are available in limited laboratories and they are expensive. For this reason, limited use is only possible in certain diseases. Genetic study results were available in only our 29 patients. As a result of these evaluations, only one case of mitochondrial myopathy could not be genetically confirmed (Table 3).

One of the most remarkable points in our study was that five patients were diagnosed with glycogen and lipid storage disorders. Four of them had been admitted with refractory polymyositis, and remaining patient was being explored for increased CK levels. Taking the developments in treatment and management of this group of diseases into consideration, the necessity of making histopathological diagnosis is indispensable for these diseases.

Duration between muscle biopsy and onset of the symptoms is one of the most important indicators in the study. This interval was 23 months in pediatric, and 98 months in adult patients. This longer time interval is indicative of the diagnostic difficulty in this group of diseases. It is painful and costly for the patient and relatives, and causes the process to be discontinued. At the same time, it is also tedious and time consuming in terms of researchers.

The disadvantage of our study is that due to the limitation of immunohistochemistry panel, necessary additional tests could not be done in some patients and results could not be supported with western blotting, and electron microscopy examinations. Lack of confirmatory, and supportive molecular genetic studies was a major drawback of our study.

\section{CONCLUSION}

Muscle biopsy is indispensable to establish an etiologic diagnosis and is a component of the identification of prognostic, predictive and therapeutic planning as well as diagnostic data. Laboratory efficiency is directly proportional to the quality of the samples retrieved. It is necessary to develop clinicopathological communication in order to meet all requirements in sample management. The proactive role of the pathologist in the preanalytical process is important in terms of patients' safety and acquisition of timely and accurate results.

The clinicopathological meetings and training activities about the application of the preanalytic process should be repeated at a sufficient level.

The importance of the evaluation of the results of muscle biopsy in the management of these diseases in our laboratory cannot be denied. We believe that 
by improving the technical infrastructure, eliminating immunohistochemical panel deficiencies, adding Western Blotting studies to the panel, and providing support of EM and molecular genetic studies, more productive results will be achieved.

Today, diagnosis and treatment of these group of diseases are performed voluntarily by a small group of physicians. These services, which are found only in a few cities on a national basis, are available to certain patients and physicians. National policies need to be developed to increase the interest of physicians in such diseases.

\section{Acknowledgement}

We thank Gülden Diniz, Ayça Erşen Danyeli for their technical and academic support for our muscle biopsy evaluations.

Ethics Committee Approval: T.C. Anadolu University Ethics Kommittee approval is available (29.12.2017-E.147469).

Conflict of Interest: Not available.

Funding: No financial support was received.

Etik Kurul Onayı: T.C. Anadolu Üniversitesi Etik Kurulu onayı alınmıştır (29.12.2017-E.147469).

Çıkar Çatışması: Mevcut değildir.

Finansal Destek: Finansal destek alınmamıştır.

\section{REFERENCES}

1. Victor Dubowitz, Carolina A. Sewry, Anders Oldfors, Russel Lane. Muscle Biopsy: A Practical Approach. 4rd ed. Saunders Elsevier; 2013.

2. Hans H. Goebel, Carolina A. Sewry, Roy O. Weller. Muscle Disease: Pathology and Genetics. $2^{\text {nd }}$. West Sussex, UK: Wiley; 2013.

3. Ishita Pant, Sujata Chaturvedi, Kiran Bala, Suman Kushwaha. Muscle histopathology in today's era of molecular genetics: Role and limitations. Ann Indian Acad Neurol. 2015;18(4):398402. [CrossRef]

4. R E Nakhleh. What is quality in surgical pathology? J Clin Pathol. 2006;59:669-672. [CrossRef]

5. Dastgir J, Rutkowski A, Alvarez R, Cossette SA, Yan K, Hoffmann RG, Sewry C, et al. Common Data Elements for Muscle Biopsy Reporting. Arch Pathol Lab Med. 2016 Ocak;140(1):51-65. [CrossRef]

6. Skram MK, Gulati S, Larsson E, Lindal S, Torp SH. Muscle biopsies in children an evaluation of histopathology and clinical value during a 5-year period. Ups J Med Sci. 2009 Mar;114(1):41-5. [CrossRef]

7. Nanette C. Joyce, Björn Oskarsson and Lee-Way Jin, Muscle Biopsy Evaluation in Neuromuscular Disorders. Phys Med Rehabil Clin N Am. 2012 August;23(3):609-31. [CrossRef]

8. Barohn RJ, Dimachkie MM, Jackson CE. A pattern recognition approach to patients with a suspected myopathy. Neurol Clin. 2014 Aug;32(3):569-93. [CrossRef]

9. Rabi N. Tawil, Shannon Venance. Neuromuscular Disorders. Wiley-Blackwell Oct 2011; p.9-15.

10. Diniz G, Yıldırım HT, Ünalp A, Barytcuoğlu $M$, Güzel O, Polat $M$, et al. The evaluation of muscle biopsy findings in children with neuromuscular disorders. İzmir Dr. Behçet Uz Çocuk Hast. Dergisi. 2012;2(2):62-67. [CrossRef]

11. Bing Q, Hu J, Li N, Shen HR, Zhao Z. Clinical and skeletal muscle biopsy characteristics of 25 patients with floppy infant syndrome. Clin Neuropathol. 2013;32(6):471-9. [CrossRef]

12. Moghadam-Kıa S, Oddıs CV, Aggarwal A. Approach to asymptomatic creatine kinase elevation. Cleve Clin J Med. 2016 January;83(1):37-42. [CrossRef]

13. Kodatsch I, Finsterer J, Stollberger C. Serum creatine kinase elevation in a medical department. Acta Med Austriaca. 2001;28(1):11-5. [CrossRef]

14. Rabie M, Jossiphov J, Nevo Y. Electromyography (EMG) accuracy compared to muscle biopsy in childhood. J Child Neurol. 2007;22(7):803-8 [CrossRef]

15. Vogel H, Zamecnik J. Diagnostic immunohistology of muscle diseases. J Neuropathol Exp Neurol. 2005;64:181-93. [CrossRef] 